\title{
Calcification rate and temperature effects on Sr partitioning in coccoliths of multiple species of coccolithophorids in culture
}

\author{
Heather M. Stoll ${ }^{\mathrm{a}, *}$, Christine M. Klaas ${ }^{\mathrm{b}, 1}$, Ian Probert ${ }^{\mathrm{c}}$, \\ Jorge Ruiz Encinar ${ }^{\mathrm{d}}$, J. Ignacio Garcia Alonso ${ }^{\mathrm{d}}$ \\ ${ }^{a}$ Department of Geology, University of Oviedo, c/ Jesus Arias de Velasco, s/n, 33005 Oviedo, Spain \\ ${ }^{\mathrm{b}}$ ETH Zurich, Zurich, Switzerland \\ ${ }^{\mathrm{c}}$ University of Caen, Caen, France \\ ${ }^{\mathrm{d}}$ Department of Analytical Chemistry, University of Oviedo, Oviedo, Spain
}

Received 10 July 2000; received in revised form 3 January 2001; accepted 19 January 2001

\begin{abstract}
Five common placolith-bearing coccolithophorid algae-Gephyrocapsa oceanica, Coccolithus pelagicus, Calcidiscus leptoporus, Umbilicosphaera sibogae (var. sibogae and var.foliosa), and Emiliania huxleyi - were cultured to investigate controls on Sr partitioning in coccolith calcite. For identical temperature and media composition, Sr partitioning varies by more than $30 \%$ in exponential phase cultures of the five species and is linearly related to rates of calcite production/cell $(\rho=0.91)$. Exponential phase culture experiments with three strains of C. leptoporus and six strains of $G$. oceanica at varying temperatures show variations in $\mathrm{Sr}$ partitioning of $20 \%$ and $30 \%$, respectively. With C. leptoporus, Sr partitioning is equally correlated with temperature and calcification rate $(\rho=0.8)$, which themselves are highly correlated; the slope of the relationship between $D_{\mathrm{Sr}}$ and calcification rate is comparable to that observed in all species at constant temperature. However, in G. oceanica, increased temperature appears to enhance $\mathrm{Sr}$ incorporation by up to $2 \%$ to $1.6 \%{ }^{\circ} \mathrm{C}^{-1}$ in the range of 15 to $30{ }^{\circ} \mathrm{C}$. The strong influence of calcification rate on $\mathrm{Sr}$ partitioning may be useful for inferring past variations in coccolithophorid productivity from Sr partitioning in coccolith sediments if the influence of temperature on Sr partitioning can be resolved. Because the relationship between calcite production and $\mathrm{Sr}$ partitioning is linear, a proportional change in calcification should be expressed much more strongly in the $\mathrm{Sr} / \mathrm{Ca}$ ratio of large species with rapid calcite production than in smaller species, which produce calcite more slowly. Consequently, it may be possible to separate temperature and calcification influences on coccolith $\mathrm{Sr} / \mathrm{Ca}$ by separately analyzing $\mathrm{Sr} / \mathrm{Ca}$ in species that produce calcite rapidly and those that produce calcite slowly, if both undergo comparable relative changes in calcification rates.
\end{abstract}

(c) 2002 Elsevier Science B.V. All rights reserved.

Keywords: coccoliths; coccolithophorids; strontium; $\mathrm{Sr} / \mathrm{Ca}$; paleoceanography; climate change

* Corresponding author.

E-mail addresses: heather.stoll@asturias.geol.uniovi.es (H.M. Stoll), cklaas@starbuck.uchicago.edu (C.M. Klaas), Billard@ibba.unicaen.fr (I. Probert), ruizencinar@yahoo.com (J. Ruiz Encinar),jiga@sauron.quimica.uniovi.es (J.I. Garcia Alonso).

${ }^{1}$ Now at the Department of Earth Sciences, University of Chicago, Chicago, IL, USA.

\section{Introduction}

Coccolithophorid algae are commonly regarded as the main producers of calcium carbonate in open ocean settings (e.g., Takahashi, 1994; Westbroek et al., 1994; Riegman et al., 1998; Archer et al., 2000), and con- 
sequently play important roles in the ocean's carbon and carbonate cycles. Coccolithophorids are also the only marine primary producers that leave a widespread fossil record: the coccoliths, or external plates of calcite, produced by these organisms enjoy long-term preservation above the carbonate compensation depth (CCD) worldwide. Consequently, the geochemical record preserved in coccolith calcite may provide a unique perspective on past changes in the carbon and carbonate cycle.

While the minor and trace element chemistry of foraminiferal calcite has been widely studied and used in paleoceanographic studies for over a decade, the minor element chemistry of coccolith calcite has been investigated only recently. A field study in the Equatorial Pacific suggested that the $\mathrm{Sr} / \mathrm{Ca}$ ratio of coccoliths may be related to the calcification and growth rates of coccolithophorids (Stoll and Schrag, 2000). Because $\mathrm{Sr} / \mathrm{Ca}$ ratios of seawater vary by less than $2 \%$ globally, the observed $\mathrm{Sr} / \mathrm{Ca}$ variations of $\sim 20 \%$ must reflect variations in $\mathrm{Sr}$ partitioning in coccolith calcite. The relationship between $\mathrm{Sr}$ partitioning in coccoliths and their calcification rates is consistent with control of $\mathrm{Sr}$ partitioning by calcification rate in abiogenic calcites (Lorens, 1981). Such a relationship, if confirmed by further studies, could prove a valuable tool for investigating past changes in coccolithophorid productivity and their relation with past variations in climate and the carbon cycle. In particular, coccolith $\mathrm{Sr} / \mathrm{Ca}$ may be useful to reconstruct past variations in the rain ratio of organic and carbonate carbon, hypothesized to be an important factor in glacial/interglacial atmospheric $\mathrm{PCO}_{2}$ cycles (Archer et al., 2000). In addition, it is possible that coccolith $\mathrm{Sr} / \mathrm{Ca}$ might be useful in correcting for growth rate effects on carbon isotope fractionation in coccolithophorid biomarkers, to improve estimates of past dissolved $\mathrm{CO}_{2}$ concentrations in surface waters. However, in order to apply with confidence the intriguing relationships between $\mathrm{Sr} / \mathrm{Ca}$ and calcification rate suggested by the field data, further investigation is needed. Culture studies represent an important context in which to investigate controls over minor element chemistry in coccoliths, because growth and calcification rates, along with calcification temperature, can be more reliably measured for comparison with geochemical data. In addition, these relationships can be evaluated for individual species, which has not yet been possible in sediment samples.
In this work, we present results of culture studies with five species of coccolithophorids algae with the aim of elucidating the controls of $\mathrm{Sr}$ partitioning in coccoliths. The relationships between $\mathrm{C}$-isotope fractionation in coccolithophorids and $\mathrm{Sr}$ partitioning in coccoliths is being investigated in a separate and concurrent study (e.g. Stoll et al., 2002a) and are not presented here.

Nearly all previous culture studies of coccolithophorids have focused on a single species, Emiliania huxleyi. In part, this is because only E. huxleyi and its close relative Gephyrocapsa oceanica, produce alkenone biomarkers. The undersaturation ratio of these biomarkers $\left(\mathrm{Uk}_{37}{ }^{\prime}\right)$ is widely used in paleotemperature reconstructions (Prahl and Wakeham, 1987), and carbon isotopic fractionation in alkenones is used to reconstruct past dissolved $\mathrm{PCO}_{2}$ concentrations in ocean surface waters (Jasper and Hayes, 1990; Jasper et al., 1994). In addition, culture studies of $E$. huxleyi have been extensively used to study coccolithophorid ecology, because E. huxleyi occurs widely throughout the modern ocean, is known to form large seasonal blooms, especially in the North Atlantic, and has been relatively easy to maintain in culture. However, since E. huxleyi is one of the smaller coccolithophorids and has a low coccolith weight, it is rarely a significant fraction $(>10 \%)$ of coccolith calcite in sediments (Broerse, 2000). Consequently, in order to interpret the chemistry of coccoliths in ocean sediments on the basis of culture studies, it is critical to investigate the species that dominate coccolith carbonate in marine sediments. Significant contributors to coccolith carbonate in sediments are Coccolithus pelagicus at high latitudes, and G. oceanica and Calcidiscus leptoporus at low latitudes (Young and Ziveri, 2000). In this work, we present results on the chemistry of coccoliths from cultures of G. oceanica, C. pelagicus, C. leptoporus, Umbilicosphaera sibogae (var. sibogae and var. foliosa), and E. huxleyi.

Since calcification rates may be an important control on $\mathrm{Sr}$ partitioning in coccoliths, we first describe calcite production rates in three strains of G. oceanica at different temperatures, and one strain of C. leptoporus at a single temperature. We also present basic calcite production data for the other species. This data enables us to compare Sr partitioning with calcite/cell and coccolithophorid calcification 
rates, in addition to culture temperature and cell division rates. We determine $\mathrm{Sr}$ partitioning in coccoliths for the five different species of coccolithophorids grown in similar culture conditions, in coccoliths from six strains of $G$. oceanica cultured at different temperatures and nutrient concentrations, and in coccoliths from three strains of $C$. leptoporus cultured at different temperatures. This dataset provides a reasonably coherent perspective on controls of $\mathrm{Sr}$ partitioning in coccolith calcite.

\subsection{Kinetic and thermodynamics of Sr substitution in calcite}

Kinetic effects strongly influence $\mathrm{Sr}$ incorporation in abiogenic calcites. Increasing the calcite precipitation rate over two orders of magnitude results in a five-fold difference in the effective $\mathrm{Sr}$ partitioning coefficient (Lorens, 1981; Tesoriero and Pankow, 1996). Watson (1996) attributed this dependence to surface enrichment effects during crystal growth, while Morse and Bender (1990) invoke surface reaction kinetics in general.

Thermodynamic effects on $\mathrm{Sr}$ incorporation in calcite cannot be established. Because $\mathrm{Sr}^{2+}$ has a larger ionic radius than $\mathrm{Ca}^{2+}, \mathrm{Sr}$ forms a solid solution series with the orthorhombic aragonite structure rather than the rhombohedral calcite structure. Consequently, $\mathrm{Sr}$ substitution in calcite is very limited and deviates significantly from ideal solid solution behavior (Tesoriero and Pankow, 1996). Sr substitution in calcite is best described as ion camouflage phenomena rather than true solid solution; consequently, thermodynamic laws cannot predict equilibrium partitioning.

\subsection{Ecology of coccolithophorid species studied}

All of the five species cultured in this study form heterococcoliths, radial arrays of complex-shaped crystals of calcite, whose final morphologies are placoliths, two disc-like shields connected by a tube. All heterococcoliths are produced intracellularly and are subsequently passed through the cell membrane, forming a continuous covering around the cell (see deVrind-deJong et al., 1994; Young et al., 1999 for a detailed discussion of calcification in coccolithophorids). In some of the culture experiments with $G$. oceanica and C. leptoporus, multiple layers of cocco- liths are formed around the cell. In addition, coccoliths may be shed from the cell, especially during later growth stages as cell division rates cease, a phenomena especially common for G. oceanica and E. huxleyi.

Placolith-bearing forms generally dominate in areas of upwelling (coastal or open ocean) and coastal and shallow-sea assemblages. G. oceanica and E. huxleyi can form large seasonal blooms as well. All of these represent eutrophic environments in which rapid population growth can occur (Young, 1994).

\section{Methods}

\subsection{Culture methods}

To compare calcification and calcite chemistry of coccoliths under different environmental conditions, six strains of G. oceanica were cultured at ETH Zurich at temperatures ranging from 17 to $30{ }^{\circ} \mathrm{C}$. Precision of measurements of culture temperatures is $\pm 0.65^{\circ}$. Three strains of $C$. leptoporus were cultured at temperatures ranging from 17 to $22{ }^{\circ} \mathrm{C}$. G. oceanica strains were isolated from the warm, oligotrophic Gulf Stream off the coast of Miami (A 4725 and A 4727), and from more temperate areas in the Western Atlantic (PC71 and ARC3) and Mediterranean (JS8 and ESP 186). Details on all the strains and their location and date of collection are given in Appendix A. The strains were preadapted to experimental conditions for approximately nine generation periods before collection of samples or growth rate data. Sixty-milliliter batch cultures were grown in coastal seawater enriched in nutrients, vitamins, and trace metals. Most experiments were conducted with nutrient enrichment at $f / 2$ levels, although some experiments were conducted at $f / 20$ and $f / 200$ nutrient levels (Guillard, 1975); nutrients were always in excess during logarithmic growth phase. Cultures were maintained in light-saturating conditions $\left(175 \pm 25 \mu \mathrm{E} \mathrm{m} \mathrm{m}^{-2} \mathrm{~s}^{-1}\right)$ on a $14 \mathrm{~h}$ light/10 h dark cycle. Cultures were semicontinuous, maintained in the log growth phase via frequent transfers, and samples were always collected in log-phase except where noted. Cultures were grown in Erlenmeyer flasks with cotton stoppers to maintain airmedia $\mathrm{CO}_{2}$ exchange but prevent bacterial invasion. Frequent cell density measurements with a haemocy- 
tometer permit precise calculation of log growth rates for each culture experiment. For each strain at each culture conditions, the length and width of the coccosphere were also measured as part of a study on morphometrics (Klaas et al., in preparation).

To compare chemistry of coccoliths of different species under similar environmental conditions, a single strain each of $E$. huxleyi, G. oceanica, $C$. pelagicus, C. leptoporus, U. sibogae sibogae, and $U$. sibogae foliosa were cultured at the University of Caen. Three-hundred-milliliter batch cultures were grown in filter-sterilized coastal seawater enriched in nutrients, vitamins, and trace metals to standards for K/2 medium (Keller et al., 1987); nutrients were always in excess during logarithmic growth phase. Cultures were grown at $17{ }^{\circ} \mathrm{C}$ (acclimated as above) in light saturating conditions on a 14:10 LD cycle. Cultures were initiated in log phase and were sampled multiple times in both log and stationary phase over a 2- to 3-week period. Cell density and culture medium $\mathrm{pH}$ were measured at each sampling point. Cell diameter and coccosphere diameters were also measured for cells in exponential phase (Table 1). Log phase growth rates are calculated from cell density changes between sampling intervals. Because of the large range in cell sizes in different species, in addition to cell division rate, is it also useful to estimate the rate of organic $\mathrm{C}$ uptake by the cells, equivalent to the organic $\mathrm{C}$ quota of the cell times the cell division rate. If we assume that $\mathrm{C}$ quota is proportional to biovolume (reasonable for the small cell sizes of these algae where vacuoles are not important (H. Kinkel, personal communication, 2000)), it is possible to estimate carbon quotas from the biovolume of these cells. We calculate pg organic

Table 1

Cell and coccosphere sizes from Caen cultures $\left(17{ }^{\circ} \mathrm{C}\right)$

\begin{tabular}{lccc}
\hline Species & $\begin{array}{l}\text { Cell } \\
\text { diameter } \\
(\mu \mathrm{m})\end{array}$ & $\begin{array}{l}\text { Coccosphere } \\
\text { diameter } \\
(\mu \mathrm{m})\end{array}$ & $\begin{array}{l}\text { pg } \\
\text { calcite/ } \\
\text { cell }\end{array}$ \\
\hline E. huxleyi (MS1) & 3.48 & 5.44 & 28 \\
G. oceanica (JS1A) & 5.09 & 7.47 & 186 \\
C. leptoporus (PC11M2) & 11.34 & 16.25 & 1600 \\
C. pelagicus (KL2) & 14.11 & 16.25 & 836 \\
U. sibogae sibogae (ASM36) & 7.11 & 25.01 & 252 \\
U. sibogae foliosa (ESP6 M1) & 8.75 & 12.63 & 398 \\
\hline
\end{tabular}

C/biovolume relationships from experiments with $E$. huxleyi, indicating typical cell quotas of $20 \mathrm{pg}$ organic $\mathrm{C} /$ cell with cell diameters of approximately $4 \mu \mathrm{m}$ (Fernandez et al., 1996).

\subsection{Measuring coccolith chemistry}

From cultures at ETH, a variable amount of culture was centrifuged to concentrate cells. The pellet was rinsed in distilled water and dried at 50 ${ }^{\circ} \mathrm{C}$. Harvested samples in most cases represent a composite sample from three replicate cultures grown in parallel. In some of the experiments at $17{ }^{\circ} \mathrm{C}$, samples from the three replicates were harvested and analyzed separately. In preparation for $\mathrm{Sr} / \mathrm{Ca}$ analysis, samples of $40-80 \mu \mathrm{g}$ carbonate were briefly sonicated then centrifuged with the following series of rinses: ethanol, acetone, methanol, $0.001 \mathrm{~N} \mathrm{HNO}_{3}$, and distilled water. Differences in $\mathrm{Sr} / \mathrm{Ca}$ for cleaned and noncleaned replicates were indistinguishable from analytical uncertainty since no major contaminant phases significantly affect carbonate $\mathrm{Sr} / \mathrm{Ca}$ ratios. Organic fractions do not contain significant $\mathrm{Sr}$ or $\mathrm{Ca}$ relative to carbonates and seawater $\mathrm{Sr} / \mathrm{Ca}$ ratios are similar to carbonate $\mathrm{Sr} / \mathrm{Ca}$ ratios. Subsequently, samples were dissolved in $200 \mu$ of $2 \%$ ultrapure $\mathrm{HNO}_{3}$.

For cultures at Caen, $10 \mathrm{ml}$ of culture was centrifuged down to concentrate cells, except for the first sampling of each culture (Day 3) where a larger but unrecorded culture volume was sampled. The pellet was rinsed twice in distilled water and dried at $50{ }^{\circ} \mathrm{C}$. Prior to splitting for analysis of calcification and $\mathrm{Sr} / \mathrm{Ca}$ ratios, the samples were rinsed in ethanol and methanol. For $\mathrm{Sr} / \mathrm{Ca}$ measurements, samples were rinsed again in ethanol and distilled water (with $\mathrm{pH}$ adjusted to 8.5 with $\mathrm{NH}_{4} \mathrm{OH}$ ) prior to dissolution in $50 \mu \mathrm{l}$ of $2 \%$ ultrapure $\mathrm{HNO}_{3}$.

$\mathrm{Sr} / \mathrm{Ca}$ was measured via inductively coupled plasma-mass spectrometry (ICP-MS) on a Finnigan ELEMENT sector field instrument in the Department of Analytical Chemistry at the University of Oviedo. Ratios were measured in pulse-counting mode on dilute solutions (10 ppm Ca). Matrixmatched standards were used to correct for mass bias and detector dead time. Precision of the analyses is better than $0.4 \%$ relative standard deviation (rsd). 


\subsection{Measuring calcification}

Calcite production was monitored throughout $\log$ phase growth in several of the ETH culture experiments. Five to ten milliliters of well-mixed culture solution were filtered onto a $25 \mathrm{~mm}$ polycarbonate filter. The filter was well rinsed with buffered distilled water to remove seasalts and dried. Filters were acidified to dissolve calcium carbonate, and the concentration of $\mathrm{Ca}$ was measured via flame atomic absorption spectroscopy on a Pye-Unicam SP9 instrument in the Department of Geology at the University of Oviedo. Precision of the Ca measurement is better than $2 \%$ (rsd), based on replicate analyses of the same sample. However, precision of the overall measurement of calcite production averages $7 \%$ (rsd) based on analysis of replicate samples collected from the culture on the same day. This latter precision is of the same order of magnitude as for cell counts, suggesting that variation may result from inhomogeneous distribution of cells in a small subsample of the culture. Because rigorous cleaning was not necessary for $\mathrm{Sr} /$ $\mathrm{Ca}$ measurements, we were also able to measure $\mathrm{Sr} / \mathrm{Ca}$ ratios of some of the coccolith samples dissolved from polycarbonate filters.

Calcite production was estimated in samples cultured at Caen by suspending the harvested coccolith pellet in $1 \mathrm{ml}$ of ethanol and extracting an aliquot of $50 \mu 1$. This carbonate was dissolved in acid and the $\mathrm{Ca}$ concentration was also measured via flame atomic absorption spectroscopy. These estimates are less precise than those for the ETH cultures, given greater uncertainty in the volume of culture harvested, and the possibility of inhomogeneous distribution of carbonate when the sample suspension was split.

Like all commonly used methods for measuring calcification rates and calcite production (e.g. ${ }^{14} \mathrm{C}$ incorporation, filter weight, etc.), these measurements are independent of whether the coccoliths are attached to the cells or loose in the media. While these methods measure net, rather than gross, calcite production, redissolution of calcite in the media is generally believed to be minor. Our measurements represent integrated calcification rates over a period of up to several days. However, "instantaneous" calcification rate determinations (via ${ }^{14} \mathrm{C}$ incorporation) and determinations of integrated calcite production in previous culture experiments with E. huxleyi are consistent and suggest rather continuous calcite production during the photoperiod (e.g. Nimer and Merrett, 1992; Dong et al., 1993).

\section{Calcite production in coccolithophorids}

\subsection{Comparing calcification in G. oceanica under different culture conditions}

G. oceanica strains cultured at ETH produce between 50 and $400 \mathrm{pg}$ calcite/cell. The calcite produced in each culture experiment is plotted as a function of cell density in Fig. 1. In Gulf Stream strains A4725 and A4727 (Fig. 1a), calcification is relatively constant with increasing cell density (Fig. 1a). For these strains, there is a consistent increase in calcification with temperature (Fig. 1b).

The temperate $G$. oceanica strain ARC3 produces more calcite per cell than the tropical strains, a maximum of $400 \mathrm{pg} / \mathrm{calcite}$ per cell, and exhibits decreasing calcification per cell at higher cell densities (Fig. 1c). Upon transfer from a dense culture to a new culture, calcite production increases rapidly. The decrease in calcification at higher cell densities likely results from a more rapid drawdown of $\mathrm{Ca}$ (and alkalinity) in the media of these high-calcifying temperate strains compared to the lower-calcifying tropical strains, combined with the higher overall cell densities reached in the high-calcifying cultures. However, it is possible that this is not truly a decrease in calcite production but an increase in the dissolution of calcite, perhaps of loose coccoliths, in the media. Brownlee et al. (1994) showed that in E. huxleyi, calcification rates decreased with decreased concentrations of $\mathrm{Ca}^{2+}$ in media. In Fig. 1d, we plot, for all strains and temperatures, the $\mu \mathrm{g}$ calcite/ml of culture media, proportional to the drawdown of $\mathrm{Ca}^{2+}$ in the culture. All strains show a change in slope of calcite production vs. cell number at $60 \mu \mathrm{g}$ of calcite $/ \mathrm{ml}$. Since for a given cell density, ARC 3 strains have higher drawdown of alkalinity than A4727 and A4725 strains, the tendency of decreasing calcification with higher cell densities is more pronounced.

Given the change in calcification with cell density, it is more difficult to compare calcite production under different culture conditions for the ARC3 strains. Fig. 1c suggests that calcite production is 
a)

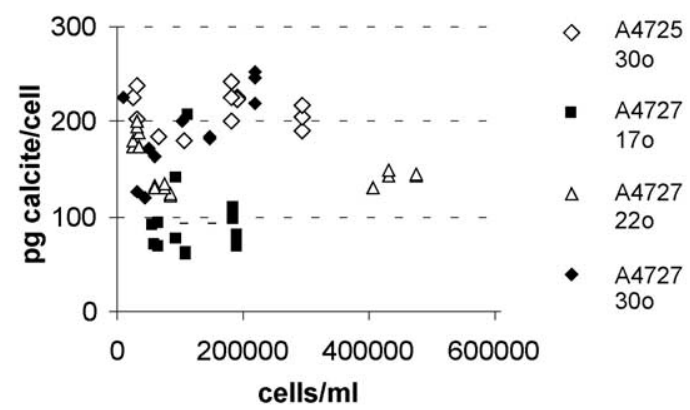

c)

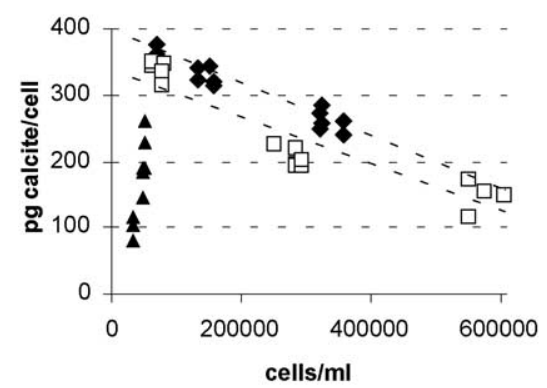

b)

Gulf Stream strains

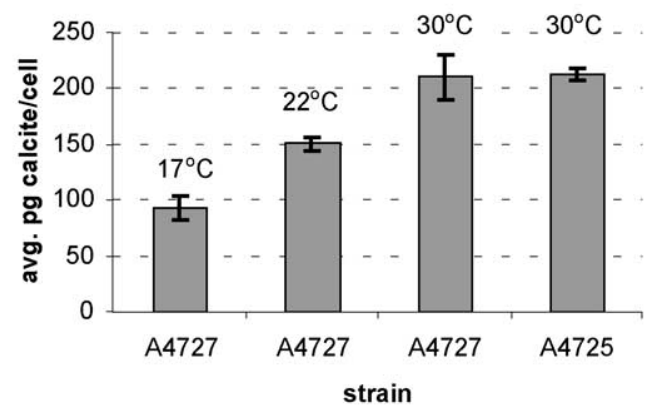

d)

all strains

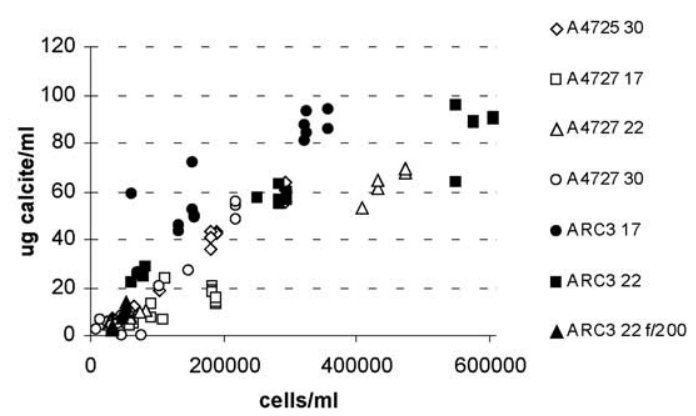

Fig. 1. Calcite production in G. oceanica strains cultured at ETH. (a) pg calcite/cell for Gulf stream strains A4725 and A4727 plotted vs. cell density. (b) Average pg calcite/cell for G. oceanica Gulf Stream strains A4725 and A4727. Average of all experiments run for that strain at a given temperature; error bars are the standard error of the mean. (c) pg calcite/cell vs. cell density for ARC 3 strains grown at different temperature and nutrient conditions. Trendlines are given for 17 and $22{ }^{\circ} \mathrm{C}$ experiments at $f / 2$ nutrient levels. Equation for $17{ }^{\circ} \mathrm{C}$ experiment is $y=-3.98 \times 10^{-4} x+3.98 \times 10^{2}$; for the $22{ }^{\circ} \mathrm{C}$ experiment is $y=-3.54 \times 10^{-4} x+3.92 \times 10^{2}$. (d) $\mu \mathrm{g}$ of calcite/ml culture volume vs. cell density for all G. oceanica calcite production data from ETH cultures. Open symbols indicate Gulf Stream strains with relatively constant calcification/cell with increasing cell density, whereas solid symbols indicate higher-calcifying temperate strain ARC3, which exhibits decreasing calcite/cell with increasing cell density.

lower for the $22{ }^{\circ} \mathrm{C}$ conditions than the $17{ }^{\circ} \mathrm{C}$ conditions by $\sim 40 \mathrm{pg}$ calcite/cell. We calculate an average of 338 and $361 \mathrm{pg}$ calcite/cell, respectively, for cultures with cell densities in the range of 60,000 to 80,000 cells $/ \mathrm{ml}$ (where maximum calcification is obtained). A linear curve fit yields $y$-intercepts of 398 and 339, respectively. Given that cell densities for the f/200 experiment do not overlap with the other experiments, it is not possible to compare calcite production.

For both Gulf Stream and temperate strains, there is a strong positive relationship between pg calcite/cell and coccosphere length and coccosphere surface area (Fig. 2). This relationship could be controlled by cell size, where larger cells have a greater surface area to cover with calcite. However, in these cultures, $G$. oceanica in many cases added multiple layers of coccoliths, so most likely that the correlation between larger coccospheres (and larger coccosphere surface area) and higher calcite/cell results from multiple layers of coccoliths. This linear relationship between pg calcite/cell and coccosphere surface area shows a consistent slope between the temperate and Gulf Stream strains despite differences in their ecology. The consistency between coccosphere size and calcite/cell suggests either that loose coccoliths are not a significant fraction of the calcite in the culture, or that their proportion is comparable in these experiments.

Estimates of calcite/cell, combined with data on cell division rates, permit calculation of calcification 


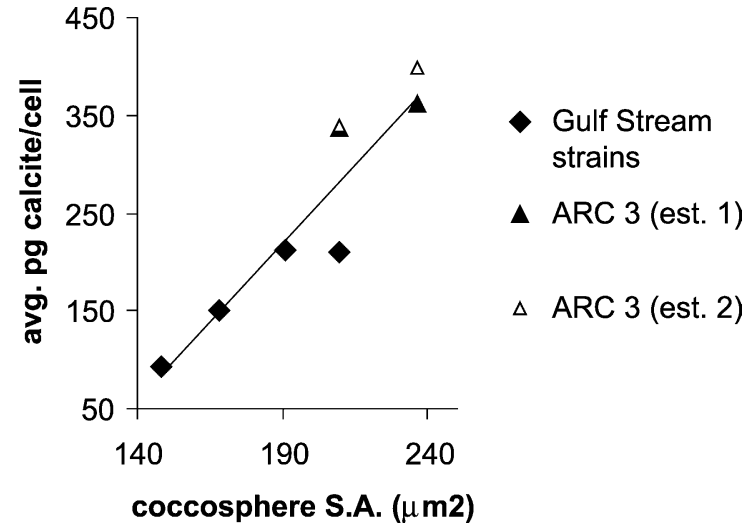

Fig. 2. Relationship between average pg calcite/cell and coccosphere surface area for $G$. oceanica strains cultured at ETH. For ARC3 strains, calcification is estimated for cell densities of 60,000 to 80,000 cells (est. 1) and by the $y$-intercept in Fig. 1c (est.2).

rates for these G. oceanica experiments. Because calcification rates may be an important control of $\mathrm{Sr}$ partitioning in coccolith calcite, it is desirable to estimate calcification rates for all strains and experimental conditions since $\mathrm{Sr}$ partitioning was measured in many more experiments than calcification. On the basis of the observed relationships between coccosphere diameter and calcite/cell in Fig. 2, we estimate calcite/cell of G. oceanica strains for experiments in which morphometric, but not calcification data, were collected. The most important caveat in this calculation is that $G$. oceanica can shed coccoliths, which could partially decouple the relationship between calcite production and coccosphere size. In addition, relationships between coccosphere size and calcification could be altered if some changes in coccosphere size are due to changes in cell size whereas others reflect merely changes in number of coccolith layers. Due to the very large coccosphere dimensions of some of the temperate strains at the highest temperatures, estimated calcification for some experiments is as high as $1000 \mathrm{pg}$ calcite/cell. For these experiments, which fall far from the range of calibrated surface area/calcite relationship, we assume a large uncertainty in subsequent discussions (and indicate these with error bars of $\pm 25 \%$ in subsequent figures). For strains where calcite/cell is likely to decrease with increasing cell density, the estimated calcite/cell represents a maximum calcite/cell and the calcification rate a maximum calcification rate. Because of these uncertainties, data on calcification rates estimated from morphological data are distinguished by different symbols in subsequent figures.

\subsection{Comparing calcification in other species under similar culture conditions}

Replicate experiments of $C$. leptoporus strain PC11 M2 $\left(17^{\circ} \mathrm{C}\right)$ cultured at ETH have much higher calcification per cell than G. oceanica, consistent with the larger cell diameter and coccosphere diameter of this species and the greater amount of calcite per coccolith. C. leptoporus cultures show a strong trend towards decreasing calcification with increasing cell density (Fig. 3a), presumably due to the very high degree of calcification and subsequent depletion of
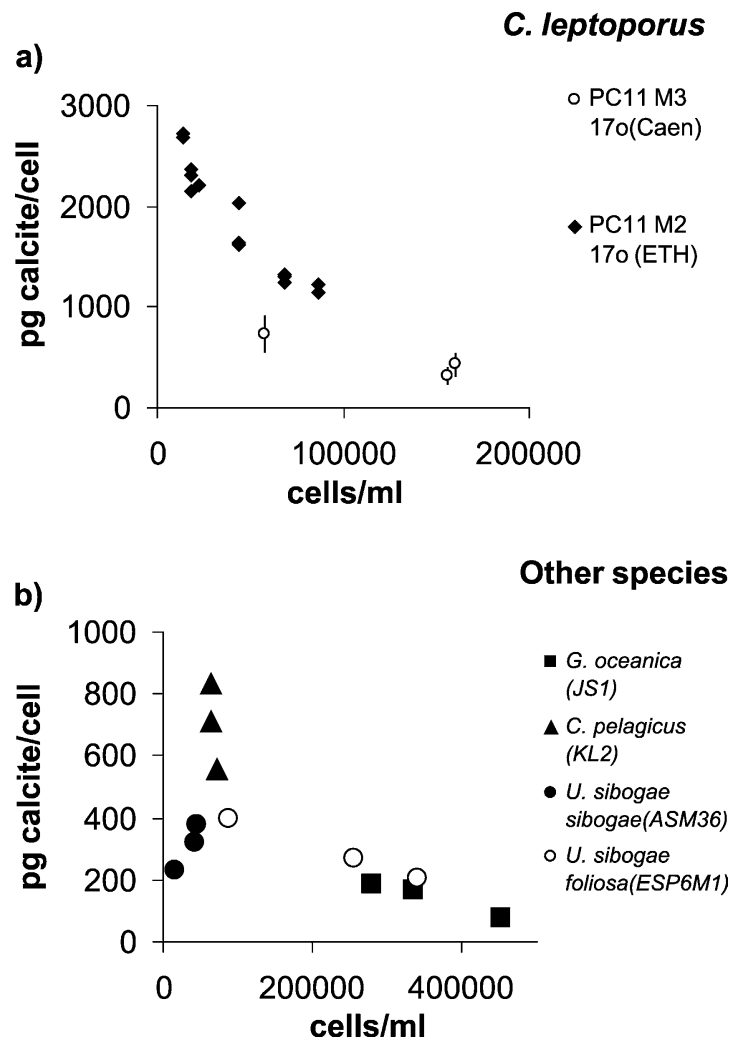

Fig. 3. Calcite production in other coccolithophorid species cultured at Caen. (a) pg calcite/cell vs. cell density for C. leptoporus at 17 ${ }^{\circ} \mathrm{C}$. (b) pg calcite/cell vs. cell density for C. pelagicus, G. oceanica (JS1), U. sibogae sibogae, and U. sibogae foliosa, at $17{ }^{\circ} \mathrm{C}$. 
media $\mathrm{Ca}^{2+}$. This trend is also observed in strain PC11 M3 $\left(17{ }^{\circ} \mathrm{C}\right)$ cultured at Caen, although this strain appears to calcify to a lesser extent than PC11 M2.

Other species cultured at $17{ }^{\circ} \mathrm{C}$ at Caen show variable degrees of calcification, from $23 \mathrm{pg}$ calcite/ cell for E. huxleyi to over $800 \mathrm{pg}$ calcite/cell for $C$. pelagicus (Fig. 3; E. huxleyi not plotted). Temperate G. oceanica strain JS1 shows similar calcite production to temperate G. oceanica strain ARC 3 discussed previously, with similar decreases in calcification with increasing cell density. Calcification in $U$. sibogae sibogae and $U$. sibogae foliosa is comparable to that in $G$. oceanica, ranging from 400 to $50 \mathrm{pg}$ calcite/cell and exhibiting similar decreases with increasing cell density.

For some of the experiments with $C$. leptoporus carried out at ETH, neither morphometric nor calcification data were collected. For these experiments, we have used the data from C. leptoporus PC11 M2 (17 ${ }^{\circ} \mathrm{C}$ ) to estimate calcite/cell and maximum calcification rates, indicating on figures the greater uncertainty in these estimates. For Caen cultures, calcification rates could be calculated only for exponential phase cultures where cell division rates are calculated.

\section{Sr partitioning in coccolith calcite}

\subsection{Calculation of Sr partitioning coefficients}

In this study, we seek to distinguish how $\mathrm{Sr}$ partitioning in coccoliths responds to different culture conditions. Hence, in measuring coccolith $\mathrm{Sr} /$ $\mathrm{Ca}$, we wish to distinguish variations due to differences in media $\mathrm{Sr} / \mathrm{Ca}$ ratio from those due to differences in $\mathrm{Sr}$ partitioning. The $\mathrm{Sr} / \mathrm{Ca}$ ratio of the stock media is essentially constant since there is very little variation in seawater $\mathrm{Sr} / \mathrm{Ca}$ ratios and since seawater for culture media is collected in large batches, which are well mixed. However, in these batch cultures, cell densities are higher than those typically encountered in natural ocean settings, and production of calcite by coccolithophorids can progressively elevate media $\mathrm{Sr} / \mathrm{Ca}$ ratios since coccolith calcite production fractionates against Sr. Media samples taken from the cultures were not appropriately preserved to permit direct measurement of media $\mathrm{Sr} / \mathrm{Ca}$ (media samples were not filtered so calcite had redissolved). However, from measurements of calcification, it is possible to calculate the media $\mathrm{Sr} / \mathrm{Ca}$ ratios. For most of the cultures, calcite production enriches the media only slightly in $\mathrm{Sr}$, although for some high calcifying strains, $\mathrm{Sr} / \mathrm{Ca}$ ratios may increase by several percent.

Here we calculate an effective Sr partitioning coefficient based on the calculated $\mathrm{Sr} / \mathrm{Ca}$ ratio of the media, although the $\mathrm{Sr} / \mathrm{Ca}$ ratio of the intracellular calcifying fluid could differ from seawater if cellular uptake mechanisms fractionate $\mathrm{Ca}$ and $\mathrm{Sr}$. Because calcite is produced continuously and media $\mathrm{Sr} / \mathrm{Ca}$ is changing, each increment of calcite is produced from media with a slightly different $\mathrm{Sr} / \mathrm{Ca}$ ratio. Consequently, to calculate the average effective $\mathrm{Sr}$ partitioning coefficient $\left(D_{\mathrm{Sr}}\right)$ of a given coccolith sample, we calculate the average media $\mathrm{Sr} / \mathrm{Ca}$ ratio weighted by the amount of calcite produced at each media composition:

$D_{\mathrm{Sr}}=\frac{(\mathrm{Sr} / \mathrm{Ca} \text { coccolith calcite })}{(\text { weighted mean } \mathrm{Sr} / \mathrm{Ca} \text { media })}$.

Weighted average media composition is solved in a spreadsheet by calculating the amount of coccolith calcite produced for each increase in cell density, based on the amount of calcite/cell measured/estimated from the calcification studies. The calculation is solved in increments of 2000 cells $/ \mathrm{ml}$ and accounts for decreasing calcification with increased cell densities in some strains. From the amount of calcite produced and a hypothetical $\mathrm{Sr}$ partitioning coefficient, we calculate the change in $\mathrm{Sr} / \mathrm{Ca}$ ratio of the media for each increase in cell density. We then calculate the average media $\mathrm{Sr} / \mathrm{Ca}$ at which the culture grew, weighted by the amount of calcite produced at each media composition. Because the model is relatively insensitive to the exact value chosen for the Sr partitioning coefficient, we are able to run it using the measured $\mathrm{Sr} / \mathrm{Ca}$ ratio for each sample. Because of uncertainties in estimating calcification for each culture, calculation of $\mathrm{Sr}$ partitioning coefficients carries additional uncertainty, which we estimate at less than $1 \%$ for $G$. oceanica. In all subsequent figures, the partitioning coefficient shown has been corrected for changes in media $\mathrm{Sr} / \mathrm{Ca}$. A vertical bar indicates the difference between partition- 
ing coefficients calculated with and without correcting for changes in media $\mathrm{Sr} / \mathrm{Ca}$, illustrating that the variability in media composition is insignificant for most samples.

For some of the experiments with $C$. leptoporus carried out at ETH, neither morphometric nor calcification data were collected. For these experiments, we have used the data from C. leptoporus PC11 M2 (17 ${ }^{\circ} \mathrm{C}$ ) and illustrate the $D_{\mathrm{Sr}}$ without correction for media composition (upper error bar), and assuming calcification/cell double that of C. leptoporus PC11 M2 (17 ${ }^{\circ} \mathrm{C}$ ) (lower error bar).

Because this model calculates iteratively the amount of calcite produced by cells, accounting for decreasing calcite/cell in some experiments, we also use it to calculate the average calcification rate for the experiments. Average calcification rate differs from the maximum calcification rate only for experiments where calcite/cell decreases with increasing cell density.

\subsection{Sr partitioning in different species at $17{ }^{\circ} \mathrm{C}$}

Where harvested separately, samples from replicate cultures of $G$. oceanica at ETH showed similar $\mathrm{Sr}$ partitioning coefficients (relative standard deviation (rsd) of 1.6\%). Because morphometric measurements used to estimate calcification for many strains are available only for the composite sample, we use the average $\mathrm{Sr}$ partitioning coefficient and growth rate for these replicate samples for subsequent figures and statistical calculations.

$\mathrm{Sr}$ partitioning coefficients for different species cultured at $17{ }^{\circ} \mathrm{C}$ range from 0.257 to 0.356 , a variation of $32 \%$ (data given in Appendix B). Among the different species, $D_{\mathrm{Sr}}$ is not correlated with cell division rate (Fig. 4a). However, for the Caen cultures where we could estimate the rate of $\mathrm{C}$ incorporation/cell/day (as described in Section 2.1), $D_{\mathrm{Sr}}$ is highly correlated with growth rates expressed in terms of $\mathrm{C}$ uptake rather than cell division (Fig. 4b; $\rho=0.94) . D_{\mathrm{Sr}}$ is also highly correlated with the average calcification rate (Fig. $4 \mathrm{c} ; \rho=0.91$ ), since calcite production/cell also varies with cell and coccosphere size (Table 1).

Slight decreases in $D_{\mathrm{Sr}}$ are observed through the growth stage of the culture (Fig. 5a), ranging from $3 \%$ in C. pelagicus, C. leptoporus, and U. sibogae
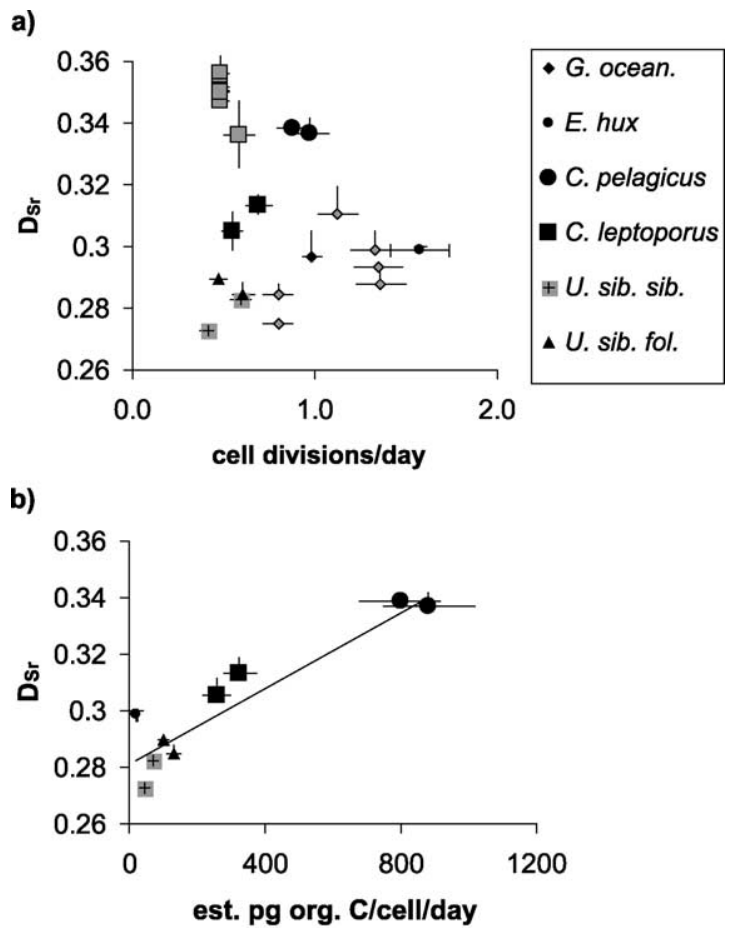

c)

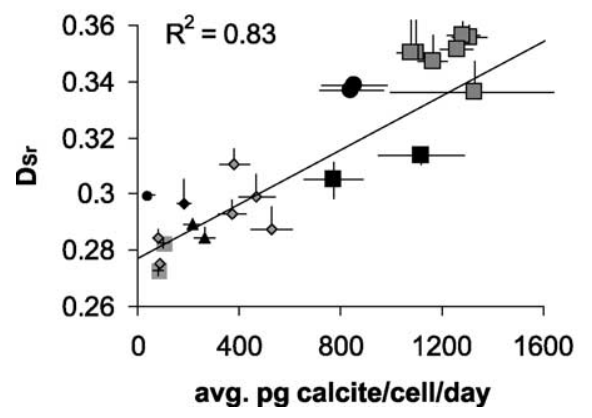

Fig. 4. $D_{\mathrm{Sr}}$ vs. cell division rate and calcification rate for all exponential phase cultures at $17{ }^{\circ} \mathrm{C}$. Upper vertical error bars indicate magnitude of correction for changes in media $\mathrm{Sr} / \mathrm{Ca}$, as described in the text (Section 4.1). Where calcification rates were not measured or estimated from morphometric data, lower vertical error bars are given, as described in the text (Section 4.1). (a) $D_{\mathrm{Sr}}$ vs. cell division rate; horizontal error bars indicate $\pm 10 \%$ uncertainty in cell division rates. (b) $D_{\mathrm{Sr}}$ vs. estimated organic C fixation rate; horizontal error bars show $\pm 15 \%$ uncertainty. (c) $D_{\mathrm{Sr}}$ vs. calcification rate; horizontal error bars indicate $\pm 5 \%$ uncertainty where calcification and $\mathrm{Sr} / \mathrm{Ca}$ were directly measured from polycarbonate filters; $\pm 25 \%$ uncertainty where calcification was not measured and no morphometric data were available; and $\pm 15 \%$ for all other cases. Equation for regression line is $y=5.56 \times 10^{-5} x+0.278$. 
a)

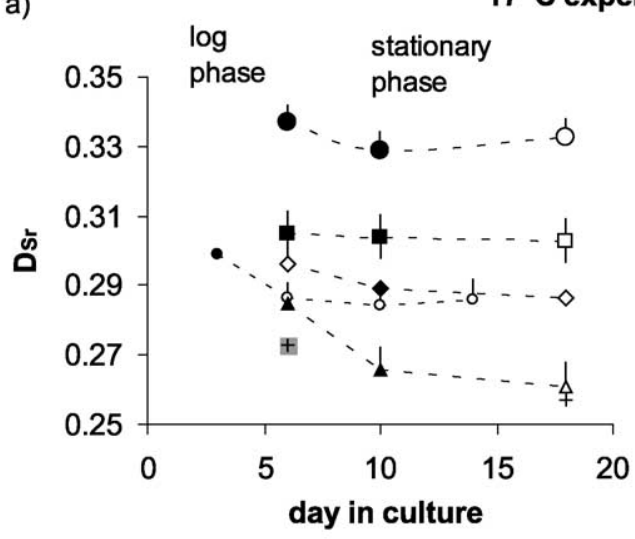

b)

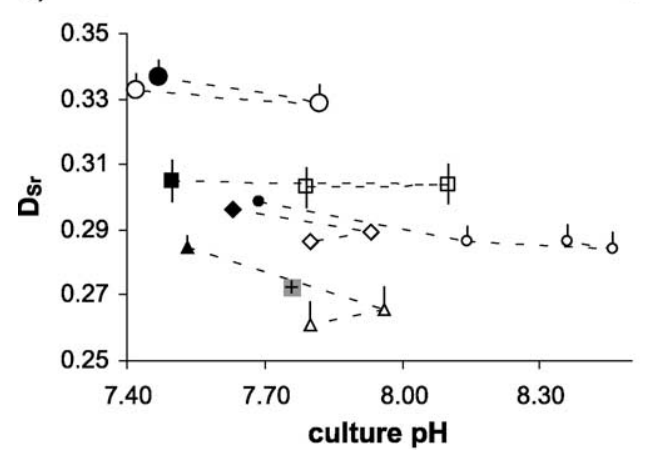

Fig. 5. (a) For Caen cultures, changes in $D_{\mathrm{Sr}}$ in different species over the course of the culture period. (b) For Caen cultures, changes in $D_{\mathrm{Sr}}$ in different species as a function of changes in media $\mathrm{pH}$ over the course of the culture period, with dashed lines connecting consecutive samples. In both (a) and (b), solid symbols indicate growth in exponential phase, open symbols indicate stationary phase. Symbol shape corresponds to different species as in Fig. 4.

sibogae, 5\% in G. oceanica and E. huxleyi, and $10 \%$ in $U$. sibogae foliosa. These decreases could correspond to slowing calcification rates in late log phase and in stationary phase; we can only estimate calcification rates for purely log phase samples. Changes in culture media may also contribute to changing $\mathrm{Sr}$ partitioning. Culture media was initially $\mathrm{pH} 7.65$, but in many cultures $\mathrm{pH}$ later approached or exceeded 8.0. De-creases in $D_{\mathrm{Sr}}$ in E. huxleyi correspond to increases in $\mathrm{pH}$; however, $D_{\mathrm{Sr}}$ is relatively stable in C. leptoporus despite even larger changes in media $\mathrm{pH}$ (Fig. 5b). Furthermore, while $D_{\mathrm{Sr}}$ generally decreased slightly a)

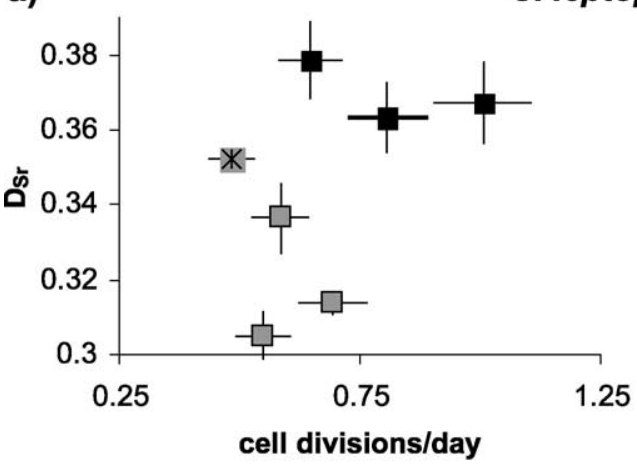

b)

C. leptoporus

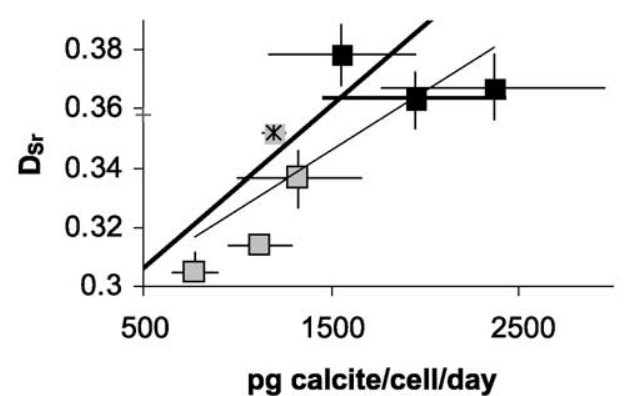

c)

C. leptoporus

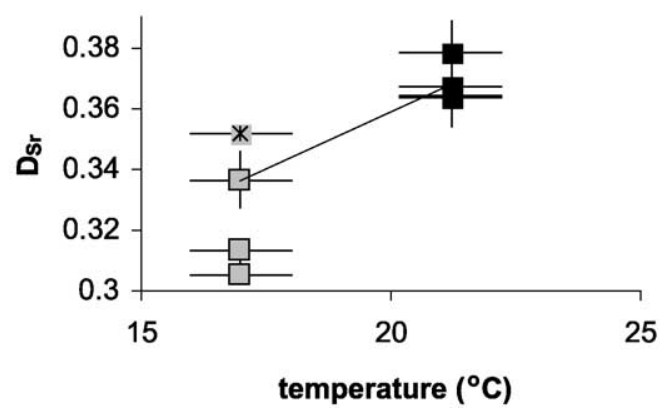

Fig. 6. C. leptoporus cultures, $D_{\mathrm{Sr}}$ vs. cell division rate (a), $D_{\mathrm{Sr}} \mathrm{vs}$. calcification rate (b), and $D_{\mathrm{Sr}}$ vs. temperature (c). Solid black symbols indicate samples cultured at $22{ }^{\circ} \mathrm{C}$, other symbols cultured at $17{ }^{\circ} \mathrm{C}$; squares with star pattern at center distinguish samples collected on polycarbonate filters for which we have precise estimates of calcification rates. In (b), bold trendline shows best fit of calcification rate vs. $D_{\mathrm{Sr}}$ for all species at $17{ }^{\circ} \mathrm{C}$ from Fig. 4 ; thin line shows best fit for $C$. leptoporus data at all temperatures $\left(y=4.02 \times 10^{-5} x+0.286\right)$. In (c), the regression line is $y=6.38 \times$ $10^{-3} x+0.228$. Vertical and horizontal error bars for (a) and (b) are as described in Fig. 4. For (c), vertical error bars are as described in Fig. 4, horizontal error bars reflect 1 degree uncertainty in temperature control of cultures. 
Table 2

Cross-correlations for C. leptoporus

\begin{tabular}{llllll}
\hline & Temperature & $\begin{array}{l}\text { Cell } \\
\text { division/ } \\
\text { day }\end{array}$ & $\begin{array}{l}\text { pg } \\
\text { calcite/ } \\
\text { cell/day }\end{array}$ & $\begin{array}{l}\text { pg } \\
\text { calcite/ }\end{array}$ & $D_{\mathrm{Sr}}$ \\
\hline cemperature & 1.00 & & & & \\
Cell division/day & 0.83 & 1.00 & & & \\
$\mathrm{pg} \mathrm{calcite/cell/day}$ & 0.87 & 0.87 & 1.00 & & \\
$\mathrm{pg}$ calcite/cell & 0.19 & -0.09 & 0.41 & 1.00 & \\
$D_{\mathrm{Sr}}$ & 0.83 & 0.47 & 0.79 & 0.93 & 1.00 \\
\hline
\end{tabular}

throughout the growth period, $\mathrm{pH}$ in many cultures increased during exponential phase but then decreased later in stationary phase. Media alkalinity may also have decreased due to calcification by as much as $1.4 \mathrm{mEq} / \mathrm{l}$, but alkalinity increases due to $\mathrm{NO}_{3}^{-}$removal in organic fractions cannot be readily calculated.

\section{3. $\mathrm{Sr}$ partitioning in C. leptoporus under different culture conditions}

At ETH, two strains of C. leptoporus were cultured at temperatures of $17{ }^{\circ} \mathrm{C}$ and $22{ }^{\circ} \mathrm{C}$. Fig. 6 illustrates the relationships between $\mathrm{Sr}$ partitioning and cell division, calcification rates, and temperature in these experiments, and cross-correlation statistics are given in Table 2. While growth rate, calcification rate, and temperature are all highly intercorrelated, $D_{\mathrm{Sr}}$ is most strongly correlated with calcification rate and temperature. The slightly weaker correlation with calcification rate as opposed to temperature may in part result from the high uncertainties of the calcification rate estimates for the $22{ }^{\circ} \mathrm{C}$ samples. In Fig. 6b, we show that the best fit line for the relationship between calcification and $\mathrm{Sr}$ partitioning in all species at constant temperature (bold line; equation in Fig. 4b) approximates well the trend in the C. leptoporus data, and falls within the $75 \%$ confidence intervals for the best fit line for the C. leptoporus data at both temperatures (thin line).

\subsection{Sr partitioning in $G$. oceanica under different culture conditions}

For the experiments with $G$. oceanica cultured at different temperatures, we distinguish the response of the Gulf Stream strains and temperate strains because

Table 3

Cross-correlations for $G$. oceanica

\begin{tabular}{|c|c|c|c|c|c|c|}
\hline & Temperature & Cell division/day & pg calcite/cell/day & pg calcite/cell & $D_{\mathrm{Sr}}$ & max pg calcite/cell/day \\
\hline \multicolumn{7}{|c|}{ (A) G. oceanica, all strains } \\
\hline Temperature & 1.00 & & & & & \\
\hline Cell division/day & 0.60 & 1.00 & & & & \\
\hline pg calcite/cell/day & 0.38 & 0.61 & 1.00 & & & \\
\hline pg calcite/cell & 0.34 & 0.51 & 0.97 & 1.00 & & \\
\hline$D_{\mathrm{Sr}}$ & 0.92 & 0.58 & 0.29 & 0.24 & 1.00 & \\
\hline $\max$ pg calcite/cell/day & 0.35 & 0.62 & 1.00 & 0.96 & 0.27 & 1.00 \\
\hline \multicolumn{7}{|c|}{ (B) G. oceanica, Gulf Stream strains } \\
\hline Temperature & 1.00 & & & & & \\
\hline Cell division/day & 0.91 & 1.00 & & & & \\
\hline pg calcite/cell/day & 0.97 & 0.97 & 1.00 & & & \\
\hline pg calcite/cell & 0.89 & 0.94 & 0.88 & 1.00 & & \\
\hline$D_{\mathrm{Sr}}$ & 0.95 & 0.90 & 0.98 & 0.77 & 1.00 & \\
\hline \multicolumn{7}{|c|}{ (C) G. oceanica, temperate strains } \\
\hline Temperature & 1.00 & & & & & \\
\hline Cell division/day & 0.86 & 1.00 & & & & \\
\hline pg calcite/cell/day & 0.64 & 0.48 & 1.00 & & & \\
\hline pg calcite/cell & 0.48 & 0.31 & 0.98 & 1.00 & & \\
\hline 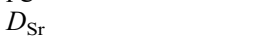 & 0.90 & 0.74 & 0.44 & 0.29 & 1.00 & \\
\hline $\max$ pg calcite/cell/day & 0.65 & 0.49 & 1.00 & 0.97 & 0.45 & 1.00 \\
\hline
\end{tabular}


they have different morphology and growth rate responses to temperature (Klaas et al., in preparation; Table 3). Overall, partitioning coefficients for Sr vary
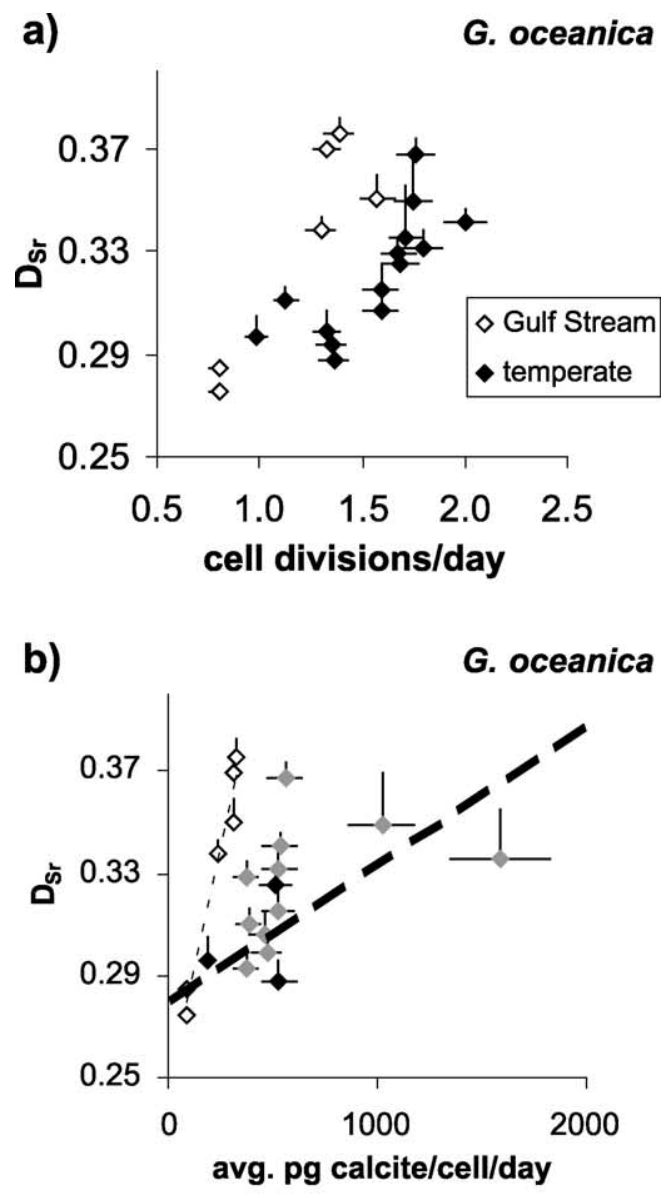

c)

G. oceanica

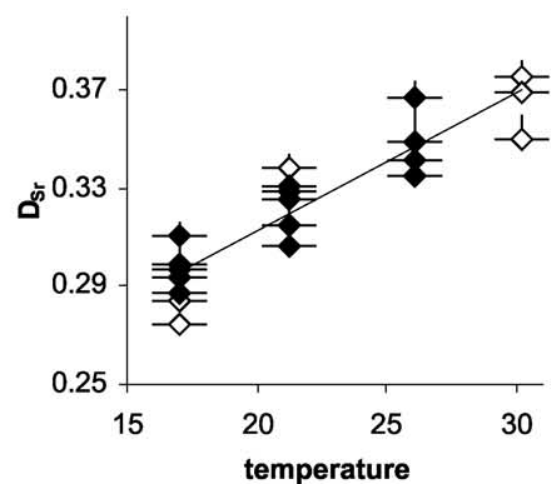

from 0.275 to 0.376 , a range of $31 \%$. Sr partitioning coefficients are correlated with cell division rates overall and for both groups of strains individually (Fig. 7 a $(\rho($ overall $)=0.58 ; \rho($ Gulf stream $)=0.90$; $\rho$ (temperate $)=0.74)$. For Gulf Stream strains, where calcification was measured directly and does not vary with cell density, $\mathrm{Sr}$ partitioning and calcification rate correlate strongly ( $\rho=0.98$; Fig. 6b). However, the slope of this relationship is much steeper than that observed between calcification rate and $D_{\mathrm{Sr}}$ in all species at constant temperature (Fig. 7b). For temperate strains, where calcification typically varied with growth rate and was in nearly all cases estimated from morphometry, $D_{\mathrm{Sr}}$ correlates more weakly with calcification rate $(\rho=0.45)$. This latter statistic is dominated by the three outliers where the estimation of calcification rate may not be reliable; it is possible that the remaining data would define a steep trend parallel to that of the Gulf Stream strains. When the two strains are considered together, $D_{\mathrm{Sr}}$ correlates only weakly with calcification rate $(\rho=0.29)$, and is most strongly correlated with temperature ( $\rho=0.92$; Fig. $7 \mathrm{c})$. For temperate strains, the correlation between $D_{\mathrm{Sr}}$ and temperature $(\rho=0.90)$ is much greater than for either cell division rate or calcification rate. For Gulf Stream strains, the difference in correlation between $D_{\mathrm{Sr}}$ and temperature $(\rho=0.95)$ and $D_{\mathrm{Sr}}$ and calcification (0.98) is not likely to be significant given the uncertainty in both measurements. Attempts to vary growth rate independent of temperature using varying nutrient concentrations were unsuccessful, as growth rates at lower nutrient levels were not significantly different from those at $f / 2$ levels. In addition, some of the lower nutrient experiments were harvested at cell densities too low to yield sufficient carbonate for $\mathrm{Sr} / \mathrm{Ca}$ analysis.

Fig. 7. G. oceanica cultures, $D_{\mathrm{Sr}}$ vs. cell division rate (a), $D_{\mathrm{Sr}} \mathrm{vs}$ calcification rate (b), and $D_{\mathrm{Sr}}$ vs. temperature (c). In (b), bold trendline shows best fit of calcification rate vs. $D_{\mathrm{Sr}}$ for all species at 17 ${ }^{\circ} \mathrm{C}$ from Fig. 4; thin dashed line shows best fit for G. oceanica (Gulf Stream strain) data at all temperatures $\left(y=3.71 \times 10^{-4} x+0.248\right)$. For (c), linear regression line is $y=5.63 \times 10^{-3} x+0.200$, but is equally well fit with exponential: $y=0.219 \mathrm{e}^{-0.0172 x}$. Vertical and horizontal error bars for (a) and (b) are as described in Fig. 4. For (c), vertical error bars are as described in Fig. 4, horizontal error bars reflect 1 degree uncertainty in temperature control of cultures. 


\section{Discussion}

\subsection{Sr partitioning: growth rate/calcification rate vs. temperature control?}

Growth rates (C-specific) and calcification rates clearly influence Sr partitioning in coccolith calcite, as observed in the tight relationships between $\mathrm{Sr}$ partitioning and calcification rates and estimated $\mathrm{C}$ incorporation rates across all investigated species at constant temperatures. Over large ranges in cell sizes, $\mathrm{C}$ incorporation rate, rather than cell division rate, is correlated with $\mathrm{Sr}$ partitioning. Over more limited ranges in cell sizes present in the same species, carbon quotas are likely to be less variable and cell division rates more correlated with $\mathrm{C}$-specific growth rates. This may explain the strong correlations between cell division rate and $D_{\mathrm{Sr}}$ in the G. oceanica experiments.

The relationships between Sr partitioning and coccolithophorid calcification and growth rates are consistent with important kinetic effects on $\mathrm{Sr}$ partitioning documented in abiogenic calcites (Lorens, 1981). In abiogenic experiments, there is a strong linear relationship between calcite precipitation rate and $D_{\mathrm{Sr}}$ for precipitation rates between 30 and $3000 \mathrm{mg}$ calcite $/ \mathrm{m}^{2}$ seed surface area/day. The coherency of the relationship between $D_{\mathrm{Sr}}$ and calcite production in coccoliths across all investigated species may be consistent with a conserved mechanism of calcite nucleation across all placolith-bearing coccolithophorids (Young et al., 1992). At constant temperature, calcification rate appears to be the most important control on $\mathrm{Sr}$ partitioning in coccolith calcites, at least in placolith-bearing heterococcoliths. Other species-specific physiological aspects of calcification must play a subordinate role in control of $\mathrm{Sr}$ partitioning in coccolith calcite.

Because temperature is highly correlated with growth rate and calcification rate, it is difficult to ascertain whether temperature exerts an independent influence on Sr partitioning in coccolith calcite. Temperature increases cell division rates in both temperate and Gulf Stream strains of G. oceanica; however, for a given temperature, growth rates are generally higher in the temperate strains. $D_{\mathrm{Sr}}$ vs. cell division rate shows different intercepts for the Gulf Stream and temperate strains, while $D_{\mathrm{Sr}}$ vs. temperature has the same relationship for both strains. The consistency of relation- ships between $D_{\mathrm{Sr}}$ and calcite production across all species at constant temperature makes it difficult to invoke ecological or physiological differences to explain the different responses of $\mathrm{Sr}$ partitioning to cell division rate in the different strains. Nonetheless, if the Gulf stream strains were characterized by larger cells than temperate strains, it is possible that the relationship between $\mathrm{C}$ incorporation rate and $D_{\mathrm{Sr}}$ would be the same for both temperate and Gulf Stream strains and that variations in $\mathrm{C}$-specific growth rate could be invoked to explain variations in $D_{\mathrm{Sr}}$. The most revealing insights may come from the tropical $G$. oceanica strain, where calcite production rates were measured directly. For this strain, the slope of $D_{\mathrm{Sr}}$ vs. calcification rates is nearly an order of magnitude greater than that observed at constant temperature across different species. This elevated slope suggests either that temperature may exert an independent influence on $\mathrm{Sr}$ partitioning in coccolith calcite, or that different factors control the response of $D_{\mathrm{Sr}}$ to interspecific vs. intraspecific variations in calcification rate. In the experiments with $C$. leptoporus at varying temperatures, the relationship between $D_{\mathrm{Sr}}$ and calcification rate is comparable to that observed at constant temperatures across all species, so temperature need not be invoked to explain $\mathrm{Sr}$ partitioning where calcification rate varied across different species. However, the relationship between temperature and $D_{\mathrm{Sr}}$ is also comparable to that observed in G. oceanica. It is possible that the separation of calcification rate and temperature effects in the C. leptoporus experiments is biased by the large uncertainties in the calcite/cell for the $22{ }^{\circ} \mathrm{C}$ C. leptoporus experiments.

If the relationship between $D_{\mathrm{Sr}}$ and temperature observed in G. oceanica is interpreted to result primarily from variations in temperature and not from the temperature effect on calcification or growth rate, the relationship corresponds to a change in $\mathrm{Sr} / \mathrm{Ca}$ ratios of $2.0 \%$ to $1.6 \%{ }^{\circ} \mathrm{C}^{-1}$ in the range of $15-30$ ${ }^{\circ} \mathrm{C}$. This is nearly an order of magnitude greater than the temperature dependence of $D_{\mathrm{Sr}}$ in calcite inferred from aragonite-calcite and dolomite-calcite transformation experiments (Malone and Baker, 1999). For calcification rate, the linear relationship in all species corresponds to a change in $\mathrm{Sr} / \mathrm{Ca}$ ratios of $2.0 \%$ to $1.6 \%$ per $100 \mathrm{pg}$ calcite/cell/day in the range of 100 to $1500 \mathrm{pg}$ calcite/cell/day. This linear relationship suggests that changes in calcification rate will be 
more clearly expressed in Sr partitioning in higher calcifying species. For example, at constant temperature, a $50 \%$ increase in calcification rate of typical $E$. huxleyi ( $28 \mathrm{pg}$ calcite/cell/day) will yield less than $1 \%$ change in $D_{\mathrm{Sr}}$, whereas a $50 \%$ increase in calcification rate of typical C. leptoporus (1200 pg calcite/cell/day) will produce a $10 \%$ change in $D_{\mathrm{Sr}}$.

\subsection{Prospects for paleoceanography}

The possible large increase in $D_{\mathrm{Sr}}$ with temperature observed in these culture experiments appears to be at odds with the field study of $\mathrm{Sr} / \mathrm{Ca}$ ratios of polyspecific coccolith assemblages where temperature does not appear to be the dominant control over $\mathrm{Sr}$ partitioning. In transects across the Equatorial Pacific upwelling front, maximum $\mathrm{Sr} / \mathrm{Ca}$ ratios at the equator correspond to maximum coccolithophorid growth and calcification rates but minimum temperatures (Stoll and Schrag, 2000). The $3.5^{\circ} \mathrm{C}$ temperature drop at the equator would be expected to produce up to a $6 \%$ decrease in coccolith $\mathrm{Sr} / \mathrm{Ca}$, whereas the observed $6 \%$ to $14 \%$ increase in $\mathrm{Sr} / \mathrm{Ca}$ compared to $\mathrm{Sr} / \mathrm{Ca}$ at $5^{\circ} \mathrm{S}$ and $5^{\circ} \mathrm{N}$, respectively, implicates an even larger increase in calcite production rate. The dominant calcite contributor to the coccolith fraction of these sediments is C. leptoporus (typically $80 \%$ by weight). Since C. leptoporus is characterized by high calcification rates, the response of $\mathrm{Sr}$ partitioning to variations in calcification rate along the transect may be amplified with respect to variations in temperature. Consequently, $\mathrm{Sr} / \mathrm{Ca}$ variations in coccolith sediments or fractions whose carbonate is dominated by small $G$. oceanica and $E$. huxleyi might be dominated by a temperature effect on $\mathrm{Sr}$ partitioning, whereas those dominated by $C$. leptoporus or $H$. carterae might be dominated by a calcification rate effect. If an independent effect of temperature on $\mathrm{Sr}$ partitioning could be confirmed, the $\mathrm{Sr} / \mathrm{Ca}$ ratio of small placolith-bearing coccolithophorids might be a sensitive indicator of past sea surface temperature, although small changes in seawater $\mathrm{Sr} / \mathrm{Ca}$ must be considered (Stoll and Schrag, 1998). Coccolith $\mathrm{Sr} / \mathrm{Ca}$ (from small coccolithophorids) might have some advantages that could complement studies of foraminiferal $\mathrm{Mg} / \mathrm{Ca}$, which has recently been proposed as an indicator of past sea surface temperatures (e.g. Nürnberg et al., 1996; Lea et al., 1999). Unlike $\mathrm{Mg} / \mathrm{Ca}, \mathrm{Sr} / \mathrm{Ca}$ is not significantly altered by contaminating phases and $\mathrm{Sr}$ distribution in coccoliths is more homogeneous than in foraminifera, where calcite of different composition may be produced during different life stages. In addition, since both the small and large placolith-bearing coccolithophorids have similar depth habitats and ecology, comparison of $\mathrm{Sr}$ partitioning in both fractions might permit reconstruction of both past temperature and calcification rate variations. Methods to separate different coccolith species from sediments are showing promise (Stoll and Ziveri, in press; Stoll et al., 2002b).

Another potential approach to separating the temperature and calcification rate effects on $\mathrm{Sr}$ partitioning may be to compare coccolith $\mathrm{Sr} / \mathrm{Ca}$ and $\mathrm{Mg} / \mathrm{Ca}$ ratios. $\mathrm{Mg}$ partitioning is likely to be affected primarily by temperature and, in contrast to $\mathrm{Sr}, \mathrm{Mg}$ partitioning in abiogenic calcites is not dependent on calcification rate (Morse and Bender, 1990). Thermodynamic calculations for $\mathrm{Mg}$ substitution in calcite (a stable solid solution series) predict that $\mathrm{Mg} / \mathrm{Ca}$ should increase exponentially by about $3 \%{ }^{\circ} \mathrm{C}^{-1}$ between 0 and $30{ }^{\circ} \mathrm{C}$ (Lea et al., 1999 from data of Koziol and Newton, 1995). For several species of foraminifera grown in culture, $\mathrm{Mg} / \mathrm{Ca}$ increases by as much as $10 \%{ }^{\circ} \mathrm{C}^{-1}$ (Nürnberg et al., 1996; Lea et al., 1999). It is likely that a similar dependence of $\mathrm{Mg}$ partitioning on temperature should exist in coccolithophorid calcite. In addition, coccolith $\mathrm{Mg} / \mathrm{Ca}$ may not be affected by media $\mathrm{pH}$ and salinity, as is foraminiferal $\mathrm{Mg} / \mathrm{Ca}$. This is because coccolithophorids produce calcite intracellularly in an environment that must be buffered to some extent with respect to media (seawater). Lea et al. (1999) suggested that in foraminifera, the increase in $\mathrm{Sr}$ partitioning with temperature $(1 \%$ ${ }^{\circ} \mathrm{C}^{-1}$ ) might result from higher $\mathrm{Mg} / \mathrm{Ca}$ ratios that favor $\mathrm{Sr}$ incorporation. Work with abiogenic calcites suggests that in the range of 2 to $10 \mathrm{~mol} \% \mathrm{Mg}$, increasing incorporation of $\mathrm{Mg}$ favors increased $\mathrm{Sr}$ incorporation (Mucci and Morse, 1983). While this may be the case for foraminifera, with of 0.3 to 1.5 $\mathrm{mol} \% \mathrm{MgCO}_{3}$ and $0.1 \mathrm{~mol} \% \mathrm{SrCO}_{3}$, it is unclear if this mechanism would be operative at the low $\mathrm{Mg} / \mathrm{Ca}$ and high $\mathrm{Sr} / \mathrm{Ca}$ of coccolith calcite $\left(0.02 \% \mathrm{MgCO}_{3}\right.$ in some of our cultures; Stoll et al., 2001). Regardless, if $\mathrm{Mg}$ partitioning reflects temperature variation, and $\mathrm{Sr}$ partitioning reflects both variation in temperature and 
calcification rates, combined measurements may permit resolution of both factors.

\section{Conclusions}

Five common placolith-bearing coccolithophorid algae were cultured to investigate controls on coccolith $\mathrm{Sr}$. Sr incorporation in coccolith calcite varied by over $30 \%$ in these experiments, and is enhanced at rapid calcification rates and at higher temperature. At constant temperature, $\mathrm{Sr}$ partitioning is linearly related to calcification rates over the entire range of species studied, consistent with a conserved mechanism for calcite nucleation across all placolith-bearing coccolithophorids suggested by Young et al. (1992, 1999). This relationship is also consistent with kinetic effects on $\mathrm{Sr}$ partitioning in abiogenic calcites (Lorens, 1981). Because this relationship is linear, a proportional change in calcification should be expressed much more strongly in the $D_{\mathrm{Sr}}$ of large species with rapid calcite production than in smaller species, which produce calcite more slowly. Consequently, efforts to utilize coccolith $\mathrm{Sr} / \mathrm{Ca}$ in sediments to estimate past variations in coccolithophorid calcification rate should focus on the larger placolith-bearing species. Experiments with several strains of $G$. oceanica suggest that temperature may increase $D_{\mathrm{Sr}}$ by up to $2 \%$ to
$1.6 \%{ }^{\circ} \mathrm{C}^{-1}$ in the range of 15 to $30{ }^{\circ} \mathrm{C}$. Consequently, temperature changes could contribute significantly to variations in coccolith $\mathrm{Sr} / \mathrm{Ca}$ in marine samples. It may be possible to separate these influences on coccolith $\mathrm{Sr} / \mathrm{Ca}$ by separately analyzing $\mathrm{Sr} / \mathrm{Ca}$ in species that produce calcite rapidly and those that produce calcite slowly, if both undergo comparable relative changes in calcification rates. Analysis of coccolith $\mathrm{Mg} / \mathrm{Ca}$ may also help distinguish the relative importance of temperature and calcification rate effects on coccolith $\mathrm{Sr} / \mathrm{Ca}$ since temperature is likely to be the primary control on coccolith $\mathrm{Mg} / \mathrm{Ca}$.

\section{Acknowledgements}

This material is based upon work supported by the North Atlantic Treaty Organization under a Grant awarded in 1998 (DGE-98-04555 to HMS) and by the II Plan Regional de Investigacion del Principado de Asturias (HMS), and by the EC-TMR project CODENET - Coccolithophorid Evolutionary Biodiversity and Ecology Network (FRMX-ET97-0113). We thank Larry Brand for assistance in collecting Gulf Stream G. oceanica isolates, Hanno Kinkel for valuable discussions and a careful reading of this manuscript, and Harry Elderfield and Dirk Nürnberg for thoughtful reviews.

Appendix A. Origin of strains cultured in this study

\begin{tabular}{|c|c|c|c|c|}
\hline Strain ID & Species & Isolated from & Date & Cultured at \\
\hline A4725 & G. oceanica & Gulf Stream, Florida, USA & $4 / 97$ & ETH \\
\hline A4727 & G. oceanica & Gulf Stream, Florida, USA & $4 / 97$ & ETH \\
\hline ARC3 & G. oceanica & Atlantic Shelf, France & $6 / 98$ & ETH \\
\hline ESP 186 & G. oceanica & Western Mediterranean, Spain & $2 / 98$ & ETH \\
\hline JS8 & G. oceanica & Southern Mediterranean & $5 / 98$ & ETH \\
\hline PC71 & G. oceanica & Atlantic Shelf, Portugal & $7 / 98$ & ETH \\
\hline PC11M2 & C. leptoporus & Atlantic Shelf, Portugal & $7 / 98$ & ETH \\
\hline PC6 & C. leptoporus & Atlantic Shelf, Portugal & $7 / 98$ & ETH \\
\hline $\mathrm{PC} 131$ & C. leptoporus & Atlantic Shelf, Ireland & $7 / 98$ & ETH \\
\hline MS1 & E. huxleyi & North Sea & 98 & Caen \\
\hline JS1 A & G. oceanica & Southern Mediterranean & $5 / 98$ & Caen \\
\hline KL2 & C. pelagicus & Atlantic Shelf, France & $12 / 99$ & Caen \\
\hline PC11M3 B & C. leptoporus & Atlantic Shelf, Portugal & $7 / 98$ & Caen \\
\hline ASM 36 & U. sibogae sibogae & Western Mediterranean (Alboran Sea) & $10 / 99$ & Caen \\
\hline ESP6 M1 & U. sibogae foliosa & Western Mediterranean, Spain & $4 / 99$ & Caen \\
\hline
\end{tabular}




\section{Appendix B}

\begin{tabular}{|c|c|c|c|c|c|c|c|c|c|c|c|c|c|}
\hline $\begin{array}{l}\text { Cultured } \\
\text { at }\end{array}$ & $\begin{array}{l}\text { Sample } \\
\text { type }\end{array}$ & Species & Strain & $\begin{array}{l}\text { Day of } \\
\text { culture }\end{array}$ & $\begin{array}{l}\text { Nutrients } \\
\text { (if not } f / 2 \text { ) }\end{array}$ & $\begin{array}{l}\text { Exper. } \\
\text { no. }\end{array}$ & Temp. & $\begin{array}{l}\text { Growth } \\
\text { phase } \\
\text { (harvested) }\end{array}$ & $\begin{array}{l}\text { Cells/ml } \\
\text { (at harvest) }\end{array}$ & $\begin{array}{l}\text { Weighted } \\
\text { average }(\mathrm{Sr} / \mathrm{Ca} \\
\text { media) }\end{array}$ & $\begin{array}{l}D_{\mathrm{Sr}} \text { (corr. } \\
\text { for media } \\
\mathrm{Sr} / \mathrm{Ca})\end{array}$ & $\begin{array}{l}D_{\mathrm{Sr}}(\text { no } \\
\text { corr. for } \\
\text { media } \\
\mathrm{Sr} / \mathrm{Ca})\end{array}$ & $\begin{array}{l}\text { Media } \\
\mathrm{pH}\end{array}$ \\
\hline ETH & lith & C. leptoporus & PC6 & & & & 17.0 & $\exp$ & 66328 & 8.83 & 0.336 & 0.347 & \\
\hline ETH & lith & C. leptoporus & PC6 & & & & 17.0 & $\exp$ & 66328 & 8.83 & 0.336 & 0.347 & \\
\hline ETH & lith & C. leptoporus & PC6 & & & & 21.2 & $\exp$ & 52500 & 8.79 & 0.367 & 0.378 & \\
\hline ETH & filter & C. leptoporus & PCIIM2 & & & -3 & 17.0 & $\exp$ & 14375 & 8.65 & 0.356 & 0.360 & \\
\hline ETH & filter & C. leptoporus & PCIIM2 & & & -1 & 17.0 & exp & 22656 & 8.70 & 0.351 & 0.357 & \\
\hline ETH & filter & C. leptoporus & PCIIM2 & & & -1 & 17.0 & exp & 44063 & 8.78 & 0.347 & 0.356 & \\
\hline ETH & filter & C. leptoporus & PCIIM2 & & & -3 & 17.0 & $\exp$ & 68242 & 8.82 & 0.351 & 0.362 & \\
\hline ETH & filter & C. leptoporus & PCIIM2 & & & -2 & 17.0 & exp & 86198 & 8.83 & 0.350 & 0.362 & \\
\hline ETH & lith & C. leptoporus & PCIIM2 & & & & 21.2 & exp & 42567 & 8.77 & 0.364 & 0.373 & \\
\hline ETH & lith & C. leptoporus & PCIIM2 & & & & 21.2 & $\exp$ & 42567 & 8.77 & 0.363 & 0.372 & \\
\hline ETH & filter & G. oceanica & A4725 & & & $-1-2$ & 30.2 & exp & 292778 & 8.72 & 0.347 & 0.354 & \\
\hline ETH & filter & G. oceanica & A4725 & & & $-2-1$ & 30.2 & exp & 180000 & 8.65 & 0.354 & 0.358 & \\
\hline ETH & lith & G. oceanica & A4725 & & & $-1 / 2$ & 30.2 & exp & 103333 & 8.61 & 0.366 & 0.368 & \\
\hline ETH & lith & G. oceanica & A4725 & & & $-2-1$ & 30.2 & exp & 110000 & 8.61 & 0.366 & 0.368 & \\
\hline ETH & lith & G. oceanica & A4727 & & & 1 & 17.0 & exp & 228889 & & & & \\
\hline ETH & lith & G. oceanica & A4727 & & & -2 & 17.0 & exp & 331333 & 8.66 & 0.284 & 0.288 & \\
\hline ETH & lith & G. oceanica & A4727 & & & -1 & 22.0 & $\exp$ & 111667 & 185.51 & 0.333 & 0.333 & \\
\hline ETH & lith & G. oceanica & A4727 & & & -2 & 22.0 & exp & 224167 & 185.51 & 0.326 & 0.326 & \\
\hline ETH & filter & G. oceanica & A4727 & & & 2 & 21.2 & exp & 83744 & 8.59 & 0.331 & 0.333 & \\
\hline ETH & filter & G. oceanica & A4727 & & & 2 & 21.2 & $\exp$ & 474815 & 8.80 & 0.357 & 0.368 & \\
\hline ETH & lith & G. oceanica & A4727 & & & 1 & 21.2 & exp & 111667 & 8.61 & 0.331 & 0.333 & \\
\hline ETH & lith & G. oceanica & A4727 & & & 2 & 21.2 & exp & 224167 & 8.67 & 0.322 & 0.326 & \\
\hline ETH & lith & G. oceanica & A4727 & & $f / 20$ & & 30.2 & exp & 110000 & 8.62 & 0.369 & 0.372 & \\
\hline ETH & lith & G. oceanica & A4727 & & & $-2 / 2-3$ & 30.2 & $\exp$ & 161111 & 8.65 & 0.404 & 0.408 & \\
\hline ETH & filter & G. oceanica & A4727 & & & $-3-2$ & 30.2 & exp & 219630 & 8.69 & 0.361 & 0.366 & \\
\hline ETH & lith & G. oceanica & A4727 & & & $-3 / 2$ & 30.2 & $\exp$ & 299167 & 8.74 & 0.364 & 0.372 & \\
\hline ETH & lith & G. oceanica & ARC3 & & & -1 & 17.0 & $\exp$ & 234306 & 8.79 & 0.287 & 0.295 & \\
\hline ETH & lith & G. oceanica & ARC3 & & & -2 & 17.0 & exp & 303056 & 8.84 & 0.284 & 0.294 & \\
\hline ETH & lith & G. oceanica & ARC3 & & & -3 & 17.0 & exp & 163889 & 8.73 & 0.292 & 0.298 & \\
\hline ETH & lith & G. oceanica & ARC3 & & $f / 20$ & & 21.2 & exp & 245000 & 8.73 & 0.331 & 0.338 & \\
\hline ETH & lith & G. oceanica & $\mathrm{ARC} 3$ & & $f / 20$ & & 21.2 & stat & 341111 & 8.76 & 0.307 & 0.314 & \\
\hline
\end{tabular}




\begin{tabular}{|c|c|c|c|c|c|c|c|c|c|c|c|c|c|}
\hline ETH & lith & G. oceanica & ARC3 & & $f / 200$ & -1 & & $\exp$ & 26953 & & & & \\
\hline ETH & lith & G. oceanica & ARC3 & & $f / 200$ & -2 & & $\exp$ & 28281 & & & & \\
\hline ETH & lith & G. oceanica & ARC3 & & & -1 & 21.2 & $\exp$ & 151667 & 8.67 & 0.324 & 0.328 & \\
\hline ETH & lith & G. oceanica & ARC3 & & & -3 & 21.2 & $\exp$ & 206111 & 8.71 & 0.327 & 0.333 & \\
\hline ETH & lith & G. oceanica & ARC3 & & & & 26.1 & $\exp$ & 200000 & 8.68 & 0.341 & 0.346 & \\
\hline ETH & lith & G. oceanica & ESP186 & & & -1 & 17.0 & $\exp$ & 140556 & 8.68 & 0.312 & 0.317 & \\
\hline ETH & lith & G. oceanica & ESP186 & & & -2 & 17.0 & $\exp$ & 161389 & 8.70 & 0.304 & 0.309 & \\
\hline ETH & lith & G. oceanica & ESP186 & & & -3 & 17.0 & $\exp$ & 195278 & 8.72 & 0.315 & 0.322 & \\
\hline ETH & lith & G. oceanica & ESP186 & & & $-1+$ & 21.2 & $\exp$ & 1157778 & 8.24 & 0.000 & 0.325 & \\
\hline ETH & lith & G. oceanica & ESP186 & & & & 26.1 & $\exp$ & 200000 & 8.70 & 0.367 & 0.374 & \\
\hline ETH & lith & G. oceanica & JS8 & & & -1 & 17.0 & $\exp$ & 169167 & 8.72 & 0.296 & 0.302 & \\
\hline ETH & lith & G. oceanica & JS8 & & & -2 & 17.0 & $\exp$ & 298611 & 8.81 & 0.299 & 0.308 & \\
\hline ETH & lith & G. oceanica & JS8 & & & -3 & 17.0 & $\exp$ & 314444 & 8.81 & 0.302 & 0.311 & \\
\hline ETH & lith & G. oceanica & JS8 & & & -2 & 21.2 & $\exp$ & 337222 & 8.70 & 0.329 & 0.335 & \\
\hline ETH & lith & G. oceanica & JS8 & & & & 26.1 & $\exp$ & 200000 & 9.05 & 0.335 & 0.355 & \\
\hline ETH & lith & G. oceanica & PC71 & & & -2 & 17.0 & $\exp$ & 229444 & 8.71 & 0.286 & 0.291 & \\
\hline ETH & lith & G. oceanica & PC71 & & & -3 & 17.0 & $\exp$ & 167778 & 8.68 & 0.297 & 0.301 & \\
\hline ETH & lith & G. oceanica & PC71 & & & -1 & 21.2 & $\exp$ & 386111 & 8.82 & 0.315 & 0.325 & \\
\hline ETH & lith & G. oceanica & PC71 & & & -2 & 26.1 & $\exp$ & 389444 & 9.05 & 0.349 & 0.370 & \\
\hline Caen & lith & E. huxleyi & MS1 & 3 & & A3 & 17.0 & $\exp$ & 445333 & 8.58 & 0.299 & 0.300 & 7.69 \\
\hline Caen & lith & E. huxleyi & MS1 & 6 & & A6 & 17.0 & exp-stat & 1914400 & 8.69 & 0.286 & 0.291 & 8.14 \\
\hline Caen & lith & E. huxleyi & MS1 & 10 & & $\mathrm{~A} 10$ & 17.0 & stat & 1906333 & 8.72 & 0.284 & 0.290 & 8.46 \\
\hline Caen & lith & E. huxleyi & MS1 & 14 & & A14 & 17.0 & stat & 1853366 & 8.72 & 0.286 & 0.292 & 8.36 \\
\hline Caen & lith & G. oceanica & JS1 A & 6 & & B6 & 17.0 & $\exp$ & 453000 & 8.79 & 0.296 & 0.305 & 7.63 \\
\hline Caen & lith & G. oceanica & JS1 A & 10 & & $\mathrm{~B} 10$ & 17.0 & stat & 335667 & 8.71 & 0.289 & 0.295 & 7.93 \\
\hline Caen & lith & G. oceanica & JS1 A & 18 & & B18 & 17.0 & stat & 279333 & 8.71 & 0.286 & 0.292 & 7.80 \\
\hline Caen & lith & C. pelagicus & KL2 & 3 & & $\mathrm{C} 3$ & 17.0 & $\exp$ & 8483 & 8.57 & 0.339 & 0.339 & \\
\hline Caen & lith & C. pelagicus & KL2 & 6 & & $\mathrm{C} 6$ & 17.0 & $\exp$ & 64400 & 8.68 & 0.337 & 0.342 & 7.47 \\
\hline Caen & lith & C. pelagicus & KL2 & 10 & & $\mathrm{C} 10$ & 17.0 & stat & 71917 & 8.69 & 0.329 & 0.334 & 7.82 \\
\hline Caen & lith & C. pelagicus & KL2 & 18 & & $\mathrm{C} 18$ & 17.0 & stat & 63667 & 8.68 & 0.333 & 0.338 & 7.42 \\
\hline Caen & lith & C. leptoporus & PC11M3B & 3 & & D3 & 17.0 & $\exp$ & 18283 & 8.63 & 0.314 & 0.317 & \\
\hline Caen & lith & C. leptoporus & PC11M3B & 6 & & D6 & 17.0 & $\exp$ & 57367 & 8.70 & 0.306 & 0.311 & 7.50 \\
\hline Caen & lith & C. leptoporus & PC11M3B & 10 & & D10 & 17.0 & exp-stat & 160667 & 8.71 & 0.304 & 0.310 & 8.10 \\
\hline Caen & lith & C. leptoporus & PC11M3B & 18 & & D18 & 17.0 & stat & 156000 & 8.72 & 0.303 & 0.309 & 7.79 \\
\hline Caen & lith & U. sibogae sibogae & ASM36 & 3 & & E3 & 17.0 & $\exp$ & 6833 & 8.55 & 0.283 & 0.283 & \\
\hline Caen & lith & U. sibogae sibogae & ASM36 & 6 & & E6 & 17.0 & $\exp$ & 16066 & 8.56 & 0.273 & 0.273 & 7.76 \\
\hline Caen & lith & U. sibogae sibogae & ASM36 & 10 & & E10 & 17.0 & stat & 43567 & 8.60 & 0.242 & 0.243 & 8.05 \\
\hline Caen & lith & U. sibogae sibogae & ASM36 & 18 & & E18 & 17.0 & stat & 45083 & 8.60 & 0.257 & 0.259 & 8.70 \\
\hline Caen & lith & U. sibogae foliosa & ESP6M1 & 3 & & F3 & 17.0 & $\exp$ & 25117 & 8.59 & 0.289 & 0.291 & \\
\hline Caen & lith & U. sibogae foliosa & ESP6M1 & 6 & & F6 & 17.0 & $\exp$ & 88800 & 8.66 & 0.285 & 0.288 & 7.53 \\
\hline Caen & lith & U. sibogae foliosa & ESP6M1 & 10 & & $\mathrm{~F} 10$ & 17.0 & exp-stat & 255667 & 8.77 & 0.266 & 0.273 & 7.96 \\
\hline Caen & lith & U. sibogae foliosa & ESP6M1 & 18 & & F18 & 17.0 & stat & 341333 & 8.78 & 0.261 & 0.268 & 7.80 \\
\hline
\end{tabular}




\section{References}

Archer, D., Winguth, A., Lea, D., Mahowald, N., 2000. What caused the glacial/interglacial $p \mathrm{CO}_{2}$ cycles? Rev. Geophys. 38, $159-189$.

Broerse, A.T.C., 2000. Coccolithophore export production in selected ocean environments: seasonality, biogeography and carbonate production. PhD Dissertation, Vrije Universiteit, Amsterdam, $185 \mathrm{pp}$.

Brownlee, C., Nimer, N., Dong, L.F., Merrett, J.M., 1994. Cellular regulation during calcification in Emiliania huxleyi. In: Green, J.C., Leadbeater, B.S.C. (Eds.), The Haptophyte Algae: Systematics Association Special Volume No. 51. Clarendon Press, Oxford, pp. 133-148.

deVrind-deJong, E.W., Van Emburg, P.R., deVrind, J.P.M., 1994. Mechanisms of calcification: Emiliania huxleyi as a model system. In: Green, J.C., Leadbeater, B.S.C. (Eds.), The Haptophyte Algae. Systematics Association Special Volume No. 51. Clarendon Press, Oxford, pp. 149-166.

Dong, L.F., Nimer, N.A., Okus, E., Merrett, M.J., 1993. Dissolved inorganic carbon utilization in relation to calcite production in Emiliania huxleyi (Lohmann) Kamptner. New Phytol. 123, 679-684.

Fernandez, E., Marañon, E., Balch, W.M., 1996. Intracellular carbon partitioning in the coccolithophorid Emiliania huxleyi. J. Mar. Syst. 9, 57-66.

Guillard, R.R.L., 1975. Culture of phytoplankton for feeding marine invertebrates. In: Smith, W.L., Chanley, M.H. (Eds.), Culture of Marine Vertebrate Animals. Plenum, New York, pp. 29-60.

Jasper, J.P., Hayes, J.M., 1990. A carbon isotope record of $\mathrm{CO}_{2}$ levels during the late Quaternary. Nature 347, 462-464.

Jasper, J.P., Hayes, J.M., Mix, A.C., Prahl, F.G., 1994. Photosynthetic fractionation of ${ }^{13} \mathrm{C}$ and concentrations of dissolved $\mathrm{CO}_{2}$ in the central equatorial Pacific during the last 255,000 years. Paleoceanography 9, 781-798.

Keller, M.D., Selvin, R.C., Claus, W., Guillard, R.R.L., 1987. Media for the culture of oceanic ultraphytoplankton. J. Phycol. 23, $633-638$.

Klaas, C., Bollman, J., Probert, I., Thierstein, H., in preparation. Morphological and physiological characterization of Gephyrocapsa oceanica: an experimental approach.

Koziol, A.M., Newton, R.C., 1995. Experimental determination of the reactions magnesite + quartz $=$ periclase $+\mathrm{CO}_{2}$ and the enthalpies of formation of enstatite and magnesite. Am. Mineral. $80,1252-1260$.

Lea, D.W., Mashiotta, T.A., Spero, H.J., 1999. Controls on magnesium and strontium uptake in planktonic foraminifera determined by live culturing. Geochim. Cosmochim. Acta 63, 2369-2379.

Lorens, R.B., 1981. Sr, Cd, Mn, and Co distribution coefficients in calcite as a function of calcite precipitation rate. Geochim. Cosmochim. Acta 45, 553-561.

Malone, M.J., Baker, P.A., 1999. Temperature dependence of the strontium distribution coefficient in calcite: an experimental study from $40^{\circ}$ to $200^{\circ}$ and application to natural diagenetic calcites. J. Sediment. Res. 69, 216-223.

Morse, J.W., Bender, M.L., 1990. Partition coefficients in calcite: examination of factors influencing the validity of experimental results and their application to natural systems. Chem. Geol. 82, $265-277$.

Mucci, A., Morse, J.W., 1983. The incorporation of $\mathrm{Mg}^{+2}$ and $\mathrm{Sr}^{+2}$ into calcite overgrowths: influence of growth rate and solution composition. Geochim. Cosmochim. Acta 47, 217-233.

Nimer, N.A., Merrett, M.J., 1992. Calcification and utilization of inorganic carbon by the coccolithophorid Emiliania huxleyi Lohmann. New Phytol. 121, 173-177.

Nürnberg, D., Bijma, J., Hemleben, C., 1996. Assessing the reliability of magnesium in foraminiferal calcite as a proxy for water mass temperatures. Geochim. Cosmochim. Acta 60, 803-814.

Prahl, F.G., Wakeham, S.G., 1987. Calibration of unsaturated patterns in long-chain ketone compositions for paleotemperature assessment. Nature 330, 367-369.

Riegman, R., Stolte, W., Noordeloos, A.A.M., 1998. A model system approach to biological climate forcing: the example of Emiliania huxleyi. Final Report Subproject (b): Physiology, Nederlands Instituut voor Onderzzoek der Zee, $32 \mathrm{pp}$.

Stoll, H.M., Schrag, D.P., 1998. Effects of Quaternary sea level changes on strontium in seawater. Geochim. Cosmochim. Acta $62,1107-1118$.

Stoll, H.M., Schrag, D.P., 2000. Coccolith $\mathrm{Sr} / \mathrm{Ca}$ as a new indicator of coccolithophorid calcification and growth rate. Geochem., Geophys., Geosystems 1, 1-24.

Stoll, H.M., Ruiz-Encinar, J., Garcia-Alonso, J.I., Rosenthal, Y., Klaas, C., Probert, I., 2001. A first look at paleotemperature prospects from $\mathrm{Mg}$ in coccolith carbonate: cleaning techniques and culture measurements. Geochemistry, Geophysics, Geosystems 8 May 2001.

Stoll, H.M., Rosenthal, Y., Falkowski, P., 2002a. Climate proxies from $\mathrm{Sr} / \mathrm{Ca}$ of coccolith calcite: calibrations from continuous culture of Emiliania huxleyi. Geochim. Cosmochim. Acta 66, 927-936.

Stoll, H.M., Ziveri, P., Geisen, M., Probert, I., Young, J.R., $2002 b$. Potential and limitations of $\mathrm{Sr} / \mathrm{Ca}$ ratios in coccolith carbonate: new perspectives from cultures and monospecific samples from sediments. Philos. Trans. R. Soc. London A 360, 719-747.

Stoll, H.M., Ziveri, P., in press. Separation of monospecific and restricted coccolith assemblages from sediments using differential settling velocity. Marine Micropaleontology.

Takahashi, K., 1994. Coccolithophorid biocoenosis: production and fluxes to the deep sea. In: Green, J.C., Leadbeater, B.S.C. (Eds.), The Haptophyte Algae. Clarendon Press, Oxford, pp. 335-350.

Tesoriero, A.J., Pankow, J.F., 1996. Solid solution partitioning of $\mathrm{Sr}^{2+}, \mathrm{Ba}^{2+}$, and $\mathrm{Cd}^{2+}$ to calcite. Geochim. Cosmochim. Acta 60, $1053-1063$.

Watson, E.B., 1996. Surface enrichment and trace-element uptake during crystal growth. Geochim. Cosmochim. Acta 60, 50135020 .

Westbroek, P., Byddemeier, B., Coleman, M., Dok, D.J., Fautin, D., Stal, L., 1994. Strategies for the study of climate forcing by calcification. In: Doumenge, F. (Ed.), Past and Present Biomineralization Processes. Considerations about the Carbonate Cycle. Bulletin de l'Institute oceanographique, Monaco, vol. 13 , pp. 37-60. 
Young, J.R., 1994. Functions of coccoliths. In: Winter, A., Siesser, W. (Eds.), Coccolithophorids. Cambridge Univ. Press, Cambridge, pp. 63-82.

Young, J.R., Ziveri, P., 2000. Calculation of coccolith volume and it use in calibration of carbonate flux estimates. Deep-Sea Res., Part 2, Top. Stud. Oceanogr. 47 (9-11), 1679-1700.
Young, J.R., Didymus, J.M., Bown, P.R., Prins, B., Mann, S., 1992. Crystal assembly and phylogenetic evolution in heterococcoliths. Nature 356, 516-518.

Young, J.R., Davis, S.A., Bown, P.R., Mann, S., 1999. Coccolith ultrastructure and biomineralisation. J. Struct. Biol. 126, $195-215$. 